dary ; (6) Pre-Quaternary micropalæontology ; (7) Ordovician and Silurian stratigraphy and correlations; (8) Late Pre-Cambrian and Cambrian stratigraphy; (9) Pre-Cambrian stratigraphy and correlations ; (10) submarine geology; (11) regional and structural problems in oil geology; (12) regional palæogeography; (13) petrographic provinces, igneous and metamorphic rocks ; (14) the granite-gneiss problem; (15) genetic problems of uranium and thorium deposits ; (16) genetic problems of ores ; (17) minerals and the genesis of pegmatites ; (18) structure of the Earth's crust and deformation of rocks ; (19) Caledonian orogeny; (20) applied geology; (21) other subjects.

As a new feature in the arrangement of the meeting, it may be mentioned that all papers selected for presentation were printed prior to the sectional meetings and delivered to the participants on their arrival-more than 4,000 pages.

During the meeting, the following affiliated associa. tions and societies held meetings: International P'alæontological Union, Association of Sedimentary Geologists, International Association of Hydrogeologists, International Mineralogical Association, Association des Services Géologiques Africains, Society of Economic Geologists, International Commission for the Study of Clays. A joint symposium was arranged by the Geochemical Society and the Geochemical Commission of the International Union of I'ure and Applied Chemistry. The KarpatoBalkanic Association also held meetings.

The following commissions of the International Geological Congress held meetings and reported to the General Assembly on the business meeting of the Congress on August 23 : (a) International Commission on Stratigraphy, with several sub-commissions (Prof. R. C. Moore resigned, and a nominating committee for electing new officers was appointed with Dr. C. J. Stubblefield as chairman); the Commission to be continued. (b) Commission of the Geological Map of Europe (Prof. A. Benz and v. Gaertner); the Commission to be continued. (c) Commission of the Geological Map of the World, with two sub-commissions (Prof. M. F. Blondel); the Commission to be continued. (d) Commission on the Gondwana System (Dr. S. H. Haughton); it was suggested that this Commission be made a sub-commission to the Commission of Stratigraphy $(a)$ with four members, one from each of the following regions: South Africa, South America, Australia and India. (e) Commission on Meteorites (report by the secretary, Dr. M. H. Hey); Commission to be continued; Prof. E. L. Krinow was elected as the new president. ( $f$ ) Commission for the Formation of an International Geo- logical Abstracting Service (Dr. H. M. E. Sehürmann) : first number of a geological abstracting journal will be issued in the beginning of 1961 by Pergamon Press. (g) Commission de la Croûte Terrestre (Prof. C. E. Wegmann and Prof. P. Fourmarier); it was proposed that the existing Commission be discontinued and that its functions concerning the establishment of a lexicon of tectonic terms handed over to the sub-commission on the tectonic map of the world (under $c$ above) and that a new organization be formed under the title, "Commission de Coordination des Recherches Géologiques et Géophysiques", with Prof. J. Goguel as president. (h) Commission for the Spendiarov Prizo; members elected and functioning during the twenty-first session were the following: D. V. Nalivkin, J. M. Harrison, V. Marmo, M. Roubault and Th. Sorgenfrei.

During the meetings an exhibition of geological maps, instruments and books was arranged in an exhibition building near the main site of the Congress. The Mineralogical and Geological Museum of the University of Copenhagen, also situated near the main site, was open daily during the poriod; more than 3,000 visitors passed the main door during the. ten days.

At meetings of the Council of the Congress, traditional questions were treated in a traditional manner. Special treatment was given to the question of the formation of a Geological Union, which was prepared by the Bureau of the Congress before being presented to the Council for decision. The Council decided at its business meeting on August 23 to appoint an organizing committee for the formation of an International Geological Union. It was further decided that the organizing committee should prepart draft statutes of the Union in order to get it estab. lished in 1961. This committee consists of the following members: N. Belyaevsky (U.S.S.R.), W. Smulikowski (Poland), B. C. Roy (India), J. M. Harrison (Canada), T. B. Nolan (U.S.A.), L. Hawkes (United Kingdom), R. Laffitte (France), E. Clar' (Austria), H. M. E. Schürmann (Netherlands), K. A. Lindbergson (Sweden), V. Marmo (Finland), A. NoeNygaard (Denmark), J. A. Dons (Norway) and T. Sorgenfrei (Denmark).

At the closing meeting of the General Assembly on August 25, Dr. Sigurdur Thorarinsson, of Reykjavik. was awarded the Spendiarov Prize for his outstanding volcanological and tephrachronological studies in Iceland. Then representatives of former host cour. tries greeted the Congress, and Dr. Roy, from India. looked forward to seeing members in 1964, at the? twenty-second Congress, in his country.

ARNE NOE-NYGaARD

\title{
POLLINATION BY INSECTS
}

" $\mathrm{P}$ OLLINATION" was the subject of a symposium held during August 12-14 at Copenhagen prior to the eleventh International Congress of Entomology in Vienna. The symposium was presided over by Prof. Eric Åkerberg of the Swedish Seed Association, and the final sessions took place at the Association's plant breeding station at Svalöf.

The importance of bees as insect pollinators has long been recognized in the production of fruit and seeds of insect-pollinated plant species, and it was therefore natural that the majority of papers were concerned with bees. In the seed production of red clover, it was clear that humble bees wero useful pollinators in every country, but the value of honey bees varied from country to country. The special difficulties of obtaining satisfactory seed yields from tetraploid red clover, however, appeared to be due as much to abnormal pollen as to the lack of suitable pollinators.

Several speakers reported work on the habits of humble bees, and various attempts to increase the population of the humble bee were described. Danish 
workers reported that certain species of humble bee had now been kept in domestication for several years, and this had enabled a much more detailed investigation of their breeding habits than had formerly been possible.

The use of 'scent direction' to improve the value of honey bees as pollinators was discussed by several contributors, but results had been somewhat varied, and it was evident that further work on this important subject is needed. Attention was directed to the varying composition of nectar between the different plant species, and the possibility that this might influence pollination was discussed. The pollination of lucerne, the subject of another session, was covered by papers describing work on this subject in North America.

At the closing session of the symposium, the following conclusions were agreed.

(1) An annual census of bumble bees would be desirable in order to identify trends in populations that could be associated with changing agricultural practices.

(2) Solution of the seed production problem in tetraploid red clover will require continued effort by plant breeders, pollination specialists and biologists.

(3) Greater effort should be given to obtaining a better understanding of the basic relationship between pollinators and flower. Identification of morphological or physiological links in those species of bees having a restricted host-range would be worth while.
(4) Pollination should be considered as one of a number of factors, and consideration should be given to them all when studying seed production. Increased effort should be given to domestication of bumble-bees. However, much more basic informa. tion needs to be developed before the full potential of this endeavour can be realized.

(5) Exchange of pollinators between countries should be oncouraged. An effort should be made to provide the proper pollinator for a given crop. This can be done by growing the crop where pollination occurs naturally, or by providing the pollinator where it does not occur naturally. A survey of all known pollinating insects for clover and alfalfa is required.

(6) Honey bees should be exploited to the maximum extent possible. Information concerning this pollinator is greater than for any of the others, and should be utilized.

(7) Scent training should be studied further; but identification of the volatile products in flowers would seem to be necessary in order to advance this phase of the work.

These recommendations, with the papers read at the symposium, are to be published in due course. The secretary of the symposium was Dr. Ole Hammer, assisted by Dr. Tom Mittler, Statens Biavlsforsøg, Strødam, Hillerød, Denmark.

R. P. Hawkins

M. S. Percival

\section{GENERATION AND APPLICATION OF ELECTROSTATIC POWER}

\begin{abstract}
$\mathrm{A}^{\mathrm{N}}$ $\mathrm{N}$ international colloquium, held under the auspices of the Centre National de la Recherche Scientifique, was held at Grenoble during September 24 -October 1 . The subjects discussed covered the generation of electrical power by electrostatic means and the applications of these machines. It is believed to have been the first international conference devoted entirely to the science of electrostatics. Due to the presence of Prof. N. J. Felici, who is the holder of the chair of olectrostatics at the University of Grenoble, this was a natural meeting place, and more than 120 engineers and physicists gathered there.

Appropriately, after a description of the early days of electrostatic machines in Grenoble, given by Prof. L. Néel, the lectures were inaugurated by Prof. Felici's discussion of the types of electrostatic generator and his hopes for the next 'generation' of electrostatic machines. This, in conjunction with a talk by Prof. J. G. Trump of the Massachusetts Institute of Technology, indicated in broad outline the scope of present possibilities and the problems of the future. There were two types of electrostatic generator in current use: first, the Van de Graaff belt-type machine, and secondly, the Felici insulating transporter cylindrical machine. Both have their advantages and disadvantages. Briefly, for high voltages and very low currents the Van de Graaff is better, and for low voltages (below one million volts) and higher currents (up to $50 \mathrm{~m}$.amp.) the Felici machines are better. For long-term continuous running, the cylinder machine is undoubtedly more reliable, but in its present state of development it cannot provide the very high voltages or current
\end{abstract}

that may be required. Prof. Trump discussed also a further type of electrostatic generator, the disk machine. This is by no means a new development, and on show at the colloquium was a very early disk-type generator built in the late 1940's at Grenoble. However, it seems to be generally agreed that this type of design has the greatest development possibilities, particularly for space travel, where the problem of insulation is much reduced.

Several papers were presented which discussed the application of this type of electrostatic generator for ion propulsion. Considerable research is being carried out both in France and the United States on electrostatic machines for this purpose. The design of a generator delivering $1,250 \mathrm{~kW}$. at $200 \mathrm{kV}$. is being investigated at the High Voltage Engineoring Corporation in Massachusetts. Parallel work is proceeding in France.

The future development of the cylinder machine is being investigated to increase the currents available, and other dielectrics, including various liquids, are being studied. Questioning elicited visualized requirements in the region from $100 \mathrm{kV}$. at 100 m.amp. to $1 \mathrm{MeV}$. at $1 \mathrm{amp}$, but no concrete suggestions as to how this might be achieved were agreed. The emphasis on ion engines for space travel was supplemented by a talk on eloctrohydrodynamic energy conversion by a representative of the U.S. Air Force.

Engineers who have been involved in the practical problems of designing the Felici generators and producing a standard range of models for industry gave a fascinating insight into the complexities of electrostatics as opposed to the comparative simplicity 